\section{Idiosyncratic reactions to carbamazepine mimicking viral infection in children}

Adverse reactions to carbamazepine include rashes, lymphadenopathy, hepatosplenomegaly, ${ }^{1}$ and bone marrow depression ranging from mild leucopenia to aplastic anaemia. ${ }^{2}$ Such reactions are rare in children. Mild leucopenia does not indicate withdrawal of the drug, but more serious bone marrow and systemic effects do. We report two cases in which the initial presentation mimicked viral infection and was associated with profound neutropenia.

\section{Case reports}

Case 1-A 1 year old girl with poorly controlled myoclonic and complex partial epilepsy developed fever and cervical lymphadenopathy eight weeks after carbamazepine had been added to her treatment. Five days later her neutrophil count had fallen from $1 \cdot 72 \times 10^{9} / 1$ to $0.25 \times 10^{9} / 1$ and the carbamazepine was stopped. After three further days the neutrophil count had returned to $1 \cdot 8 \times 10^{9} / 1$ and her clinical illness resolved. She was subsequently challenged with carbamazepine; after six days her neutrophil count had fallen to $0.85 \times 10^{9} / 1$, increasing to $3 \times 10^{9} / 1$ five days after the drug was stopped.

Case 2-A 6 year old girl with myoclonic and complex partial epilepsy developed an itchy maculopapular rash on her trunk, scalp, palms, and soles two weeks after her treatment was changed from phenytoin to carbamazepine. Palatal petechiae, cervical and inguinal lymphadenopathy, and (subsequently) hepatosplenomegaly were also found. A blood film showed "atypical lymphocytes," but there was no neutropenia (neutrophils $5.78 \times 10^{9} / 1$ ). Monospot and serial viral titres were negative, as were other indices of infection. A week later she became anorectic and lethargic. The rash had faded and become pigmented, but the lymphadenopathy and hepatosplenomegaly persisted. The neutrophil count fell to $0.07 \times 10^{9} / 1$. Carbamazepine was stopped, and over the following week her clinical condition and neutropenia resolved.

In both patients the haemoglobin concentration and platelet count remained normal, and because of this and the rapid response to withdrawal of the drug bone marrow examinations were not performed.

\section{Comment}

Both children's neutropenia was thought to have been caused by a viral illness, but their problems resolved when carbamazepine was stopped. The table summarises these and four other reported cases. In those children taking other anticonvulsant treatment the neutrophil count increased when only the carbamazepine was stopped. Challenge with carbamazepine produced recurrence of the leucopenia in our first case and of the clinical features in the case reported by Bertrand et al (case 6 in the table). ${ }^{5}$ In all patients the symptoms were initially thought to be infective (streptococcal or viral) in origin, and malignancy was also suspected in one patient.

These reactions to carbamazepine are thought to be idiosyncratic and may be due to hypersensitivity and formation of immune complexes. ${ }^{1}$ The exact prevalence of such reactions is not known; fewer than 20 cases of rash, lymphadenopathy, and fever have been reported in adults and children, and only two other cases of hepatosplenomegaly, both in adults.

It has been suggested that haematological reactions occur more commonly in adults, but Silverstein found an incidence of leucopenia of $17 \%$ in a group aged $0-12$ years and $8 \%$ in a group aged $12-17 .^{2}$ This does not appreciably differ from the generally accepted incidence of $10 \%$ in all ages. He recommended undertaking blood counts monthly for six months and then every three months. An idiosyncratic reaction to carbamazepine causing a potentially serious haematological abnormality should be considered in patients presenting with clinical symptoms of viral or streptococcal infection or of lymphoma. In these cases haematological examination is essential, but routine blood counts are unlikely to be worth while.

We thank Dr B G R Neville and Professor R J Robinson for permission to report these cases and Mrs Deirdre Gillies for typing the manuscript.

${ }^{1}$ Lewis IJ, Rosenbloom L. Glandular fever-like syndrome, pulmonary eosinophilia and asthma associated with carbamazepine. Postgrad Med $\mathcal{F} 1982 ; 58: 100-1$.

Silverstein FS, Boxer L, Johnson MV. Haematological monitoring during therapy with carbamazepine in children. Ann Neurol 1983;13:685-6.

Taylor MW, Smith SC, Hern JEC. An unexpected reaction to carbamazepine. Practitioner 1981;225:219-20.

- Prieur AM, Le Bourr Y, Griscelli C, et al. Carbamazepine agranulocytosis. Ann Pediatr (Paris) 1973;20:909-12.

Bertrand A, Janbon F, Jourdan J, et al. Intolerance to carbamazepine (Tegretol) appearing as a malignant "reticulopathy." fournal of Medicine of Montpellier

(Accepted 10 May 1984)

Department of Paediatrics, Guy's Hospital, London SE1 9RT

CAROLINE BRAIN, MRCP, paediatric senior house officer

BREEGE MAC ARDLE, MRCP, honorary registrar in paediatric neurology SIMON LEVIN, MRCP, paediatric senior registrar

Correspondence to: Dr C Brain.

\section{Doses of aminophylline given intravenously in casualty department and resulting serum theophylline concentrations}

Aminophylline is commonly given intravenously as emergency treatment for asthma and acute bronchitis, even to patients already receiving theophylline treatment who have appreciable serum theophylline concentrations. ${ }^{1}$ We noted doses of aminophylline used in a hospital casualty department, and measured the effect on serum theophylline concentrations.

\section{Patients, methods, and results}

We studied 33 consecutive adults, 22 ( 16 women, 6 men) with asthma and 11 (all men) with chronic obstructive airways disease, who received aminophylline intravenously in the casualty department. Prior treatment with theophylline orally, rectally, or parenterally was recorded. The dose of aminophylline, given over at least 10 minutes, was at the discretion of the administering doctor. Blood was taken before and one to two hours after the completed injection for assay of theophylline by the enzyme multiplied immunoassay technique (Syva).

The 22 patients with asthma and 11 with chronic obstructive airways disease had mean (SD) ages of $45 \cdot 1$ (15) and $65 \cdot 8(5 \cdot 3)$ years respectively and weighed $65 \cdot 5(15 \cdot 8) \mathrm{kg}$ and $65 \cdot 2(19 \cdot 3) \mathrm{kg}$. Fifteen with asthma and seven with

Idiosyncratic reactions to carbamazepine in children

\begin{tabular}{|c|c|c|c|c|c|c|c|c|c|c|c|}
\hline $\begin{array}{l}\text { Case No } \\
\text { and } \\
\text { reference }\end{array}$ & $\begin{array}{l}\text { Age } \\
\text { (years) }\end{array}$ & Sex & Other drugs & Rash & Pyrexia & Lymphadenopathy & Hepatomegaly & Splenomegaly & $\begin{array}{l}\text { Minimum } \\
\text { neutrophil } \\
\text { count } \\
\left(\times 10^{\circ} / 1\right)\end{array}$ & Initial diagnosis & $\begin{array}{l}\text { Response to } \\
\text { stopping } \\
\text { carbamazepine }\end{array}$ \\
\hline 1 & 1 & $\mathrm{~F}$ & $\begin{array}{l}\text { Phenytoin, } \\
\text { phenobarbitone, } \\
\text { diazepam }\end{array}$ & - & + & + & - & - & $0 \cdot 25$ & Viral infection & Resolved* \\
\hline 2 & 6 & $\mathrm{~F}$ & None & + & + & + & + & + & 0.06 & Viral infection & Resolved \\
\hline $\begin{array}{l}3^{1} \\
4^{3}\end{array}$ & $\begin{array}{r}8 \\
15\end{array}$ & $\stackrel{M}{M}$ & $\begin{array}{l}\text { None } \\
\text { None }\end{array}$ & $\begin{array}{l}+ \\
+\end{array}$ & $\begin{array}{l}+ \\
+\end{array}$ & + & $\begin{array}{l}+ \\
+\end{array}$ & $\begin{array}{l}+ \\
+\end{array}$ & & $\begin{array}{l}\text { Glandular fever } \\
\text { Streptococcal infection or }\end{array}$ & $\begin{array}{l}\text { Resolved } \\
\text { Resolved }\end{array}$ \\
\hline $5^{4}$ & 11 & $\mathrm{~F}$ & Phenobarbitone & + & + & + & + & + & 0 & $\begin{array}{l}\text { lymphoma } \\
\text { Viral infection, lymphoma, or }\end{array}$ & Resolved \\
\hline $6^{5}$ & 14 & M & $\begin{array}{l}\text { Phenobarbitone, } \\
\text { diazepam }\end{array}$ & + & + & + & - & + & & $\begin{array}{l}\text { systemic lupus erythematosus } \\
\text { Drug reaction or lymphoma }\end{array}$ & Sesolved* \\
\hline
\end{tabular}

*Relapse after challenge with carbamazepine. 